\title{
KAJIAN PENDAHULUAN KELAYAKAN PENERAPAN INSTALASI PENGOLAHAN AIR LIMBAH DOMESTIK SECARA KOMUNAL DI PERMUKIMAN KOTA BOGOR
}

\author{
Oleh : \\ Agus Rifai *) dan Rudi Nugroho *) \\ *) Universitas Diponegoro ${ }^{* *}$ Pusat Teknologi Lingkungan, BPPT.
}

\begin{abstract}
A preliminary assessment of an application of sewerage system with Upflow Anaerobic Sludge Blanket (UASB) and Down flow Hanging Sponge (DHS) technology was conducted in North Bogor. The Problem which often emerge in management of domestic wastewater is the limited land area and fund to built and operate a wastewater treatment facility. To overcome such problem, it is needed to develop a cheap wastewater treatment technology with high efficiency, easy to operate and also should be compact. The combination technology of UASB and DHS is proposed as an economic wastewater treatment which easy to handling. Therefore, to make sure that the technology is feasible or not to be built in North Bogor, there is need the preliminary assessment. The assessment was conducted through a survey of technical and social economic aspect. The results show that sewerage system using UASB and DHS technology is feasible.
\end{abstract}

Key word: domestic wastewater, upflow anaerobik sludge blanket, downflow hanging sponge, preliminary assessment.

\section{PENDAHULUAN}

\subsection{Latar Belakang}

Kecamatan Bogor Utara merupakan bagian dari Kota Bogor dengan luas administratif $1772 \mathrm{Ha}$. Sebagai wilayah perkotaan yang berlokasi dekat dengan lbukota Negara, mempunyai potensi yang strategis bagi perkembangan dan pertumbuhan ekonomi dan jasa, pusat kegiatan nasional untuk industri, perdagangan, transportasi, komunikasi, dan pariwisata. Oleh karena itu, wajar jika tingkat pertumbuhan penduduk akhir-akhir ini menunjukkan kemajuan yang signifikan.

Sistem sanitasi yang digunakan di wilayah Kecamatan Bogor Utara saat ini menggunakan sistem on-site (sistem pembuangan setempat) yaitu dengan menggunakan septik tank dan sumur resapan untuk limbah tinja. Sedangkan limbah cair yang berasal dari kegiatan dapur, kamar mandi, WC langsung dialirkan ke sistem drainase lalu ke badan air penerima. Kepadatan penduduk yang tinggi juga berpengaruh terhadap ketersediaan lahan penempatan septik tank dan sumur resapan. Meskipun septik tank sudah dilengkapi sumur resapan, tidak tertutup kemungkinan adanya air rembesan effluen tangki septik yang akan mencemari air tanah disekitarnya dan apabila air tanah tersebut dikonsumsi manusia maka dapat menyebabkan timbulnya penyakit.

Berdasarkan analisis lingkungan strategis Kota Bogor terdapat lima isu-isu yang mendapat prioritas penanggulangan, salah satunya yaitu kebersihan kota dan lingkungan hidup. Sebagai salah satu upaya penanganan masalah kebersihan kota dan lingkungan hidup, maka perlu dipertimbangkan adanya sistem penanganan air limbah domestik yang meliputi sistem penyaluran dan pengolahan terpusat yang dikenal dengan sistem off site.

Sistem penyaluran berupa sistem perpipaan sedangkan untuk sistem pengolahan terpusat dipilih suatu teknologi pengolahan air limbah domestik yang efektif dan efisien dalam rangka memperbaiki sistem kualitas sanitasi lingkungan eksisting. Diharapkan pula bahwa teknologi tersebut mengedepankan suatu produk yang dapat didaur ulang, dalam hal ini adalah produk limbah yang secara kualitas dapat digunakan kembali untuk berbagai keperluan. Teknologi tersebut yaitu Upflow Anaerobik Sludge Blanket (UASB) dan Downflow Hanging Sponge (DHS). Oleh karena itu, untuk menunjukkan pembangunan sistem penyaluran dan pengolahan terpusat air limbah domestik tersebut layak atau tidak, maka perlu dilakukan studi teknis kelayakan dan survai sosial ekonomi yang menyoroti segala macam aspek yang diperkirakan memiliki relevansi kuat dengan rencana yang bersangkutan.

\subsection{Identifikasi Masalah}

Kepadatan penduduk yang tinggi menyebabkan tidak tersedia lahan yang cukup untuk membangun septik tank dan area peresapan. Bidang peresapan yang tidak terlalu 
luas dan didukung sifat tanah dengan permeabilitas rendah mempunyai potensi kemungkinan terjadi pencemaran instalasi air bersih oleh air limbah melalui kebocorankebocoran pipa. Sistem sanitasi setempat (on site) dapat menimbulkan permasalahan berkaitan dengan aspek-aspek penanganan air limbah. Oleh karena itu untuk mengatasi dampak yang akan timbul maka perlu adanya perubahan penanganan air limbah dari sistem on-site menjadi sistem off-site. Penanganan air limbah dengan sistem perpipaan dan unit pengolahan kombinasi UASB dan DHS merupakan cara yang dapat diterapkan karena unit ini tidak memerlukan lahan yang luas, ramah lingkungan dan mudah dalam pengoperasiannya.

\section{KONDISI WILAYAH STUDI}

\subsection{Kondisi Topografi Kecamatan Bogor Utara}

\begin{abstract}
Kecamatan Bogor Utara merupakan daerah perbukitan bergelombang dengan ketinggian yang bervariasi antara 28 - $300 \mathrm{~m}$ diatas permukaan laut dengan kemiringan lereng berkisar $0-2 \%$ (datar) seluas 137,85 $\mathrm{Ha}, 2-$ $15 \%$ (landai) seluas 1.629,2 Ha dan $25-40 \%$ (Curam) seluas 4,95 Ha.
\end{abstract}

\subsection{Geologi dan Permeabilitas Tanah}

Secara Umum Kecamatan Bogor Utara ditutupi oleh batuan vulkanik yang berasal dari endapan (batuan sedimen) dua gunung berapi, yaitu Gunung Pangrango (berupa satuan breksi tupaan/kpbb) dan Gunung Salak (berupa aluvium/kal dan kipas aluvium/kpal). Lapisan batuan ini berada agak dalam dari permukaan tanah dan jauh dari daerah aliran sungai. Endapan permukaan umumnya berupa aluvial yang tersusun oleh tanah, pasir dan kerikil hasil dari pelapukan endapan yang baik untuk vegetasi. Kondisi geologi secara umum memiliki jenis tanah latosol coklat kemerahan dengan permeabilitas 15-35 liter/m² (Anonim, 2003).

\subsection{Hidrologi dan Hidrogeologi}

Wilayah Kecamatan Bogor Utara dialiri oleh satu sungai besar yaitu Sungai Ciliwung dan dialiri oleh beberapa anak sungai yang membentuk pola aliran paralel-subparalel sehingga mempercepat waktu mencapai debit puncak (time to peak) pada Sungai Ciliwung sebagai sungai utamanya. Pada umumnya aliran sungai tersebut dimanfaatkan oleh sebagian masyarakat. Selain beberapa aliran sungai yang mengalir terdapat juga beberapa mata air yang umumnya dimanfaatkan oleh masyarakat untuk kebutuhan air bersih sehari-hari. Kemunculan mata air tersebut umumnya terjadi karena pemotongan bentuk lahan atau topografi sehingga secara otomatis aliran air tanah tersebut terpotong dengan besaran debit bervariasi.

Sistem akuifer air tanah dalam berupa akuifer dengan aliran melalui celahan dan ruang antar butir. Dari peta Hidrogeologi terlihat bahwa akuifer produktifitas tinggi dengan aliran melalui celahan dan ruang antar butir dengan sebaran yang luas terdapat hampir disemua wilayah Bogor.

\subsection{Kondisi Tata Guna Lahan}

Perkembangan struktur fisik kota adalah sebagai akibat meningkatnya volume kebutuhan pelayanan umum yang memerlukan ruang untuk menunjang kegiatan yang ada dan akan terjadi, sehingga pada akhirnya akan menuntut perluasan dan itensifikasi ruang kota dalam bentuk penggunaan lahan. Pola penggunaan lahan identik dengan struktur penggunaan lahan dimana wilayah Bogor Utara memiliki luas 1.772 Ha. Dari luas wilayah tersebut terdistribusi kedalam lahan permukiman 1.118,8 $\mathrm{Ha}$ atau $63,14 \%$, lahan persawahan $298,4 \mathrm{Ha}$ atau $16,83 \%$ dan lahan bukan persawahan $354,8 \mathrm{Ha}$ atau 20,03\%. Dalam hubungan ini, dengan pertimbangan terhadap kecenderungan perkembangan struktur tata ruang yang ada, maka untuk menetapkan kegiatan utama kota pada masa yang akan datang perlu mempertimbangkan sifat dari kegiatan-kegiatan yang meliputi :

a. Pemusatan kegiatan (Aglomerasi)

b. Orientasi kegiatan

c. Skala pelayanan

d. Pertumbuhan penduduk

e. Bentuk dan struktur kota

f. Pola perkembangan

\subsection{Kondisi Sosial Ekonomi Wilayah}

\subsubsection{Jumlah dan Kepadatan Penduduk}

Kepadatan penduduk di Kecamatan Bogor Utara tidak merata karena dipengaruhi oleh penyebaran fasilitas-fasilitas pelayanan yang lain. Jumlah penduduk Kecamatan Bogor Utara pada tahun 2003 sebanyak 144.590 jiwa. Berdasarkan data menunjukkan bahwa Kelurahan Bantarjati dan Kelurahan Tegalgundil mempunyai jumlah penduduk yang paling tinggi akan tetapi mempunyai luas wilayah yang sempit yaitu cuma $1,7 \mathrm{~km}^{2}$ dan $1,98 \mathrm{~km}^{2}$. Banyaknya jumlah penduduk merupakan salah satu akibat adanya aktivitas pembangunan perumahan dan fasilitas-fasilitas kota yang semakin tinggi dibandingkan dengan kelurahan lainnya. 


\subsubsection{Tingkat Pendidikan Penduduk}

Pendidikan merupakan salah satu aspek penting yang berfungsi meningkatkan kualitas hidup masyarakat. Semakin tinggi tingkat pendidikan masyarakat, menunjukan kualitas sumber daya manusia yang semakin baik. Tingkat pendidikan masyarakat Kecamatan Bogor Utara sebagian mencapai perguruan tinggi.

\subsubsection{Jenis Mata Pencaharian Penduduk}

Mata pencaharian masyarakat di kecamatan Bogor Utara bervariasi akan tetapi sebagian besar usaha dalam bidang jasa. Hal ini erat kaitannya dengan Kota Bogor sebagai pusat kegiatan-kegiatan Internasional konfrensikonfrensi antara lain seperti Informal Meeting untuk APEC yang dihadiri oleh para pemimpin negara dari Asia Pacifik termasuk Amerika Serikat.

\subsubsection{Sarana Air Bersih}

Sistem penyediaan air bersih penduduk Kecamatan Bogor Utara terdiri dari sistem perpipaan dan nonperpipaan. Berdasarkan data dari Bidang P3KI Dinas Kesehatan Kota Bogor tahun 2004, tingkat pelayanan sistem perpipaan sudah mencapai $47,53 \%$. Sistem pelayanan perpipaan terbesar di wilayah Kelurahan Bantarjati dan Tegalgundil. Sedangkan sistem nonperpipaan yang terdiri dari sumur pompa tangan (SPT), sumur gali (SGL) dan pompa listrik banyak terdapat di Kelurahan Kedunghalang, Ciparigi dan Ciluar. Oleh karena itu resiko terhadap pencemaran sarana air bersih cukup rentan mengingat masih banyak sumber air bersih yang berasal dari nonperpipaan.

\subsubsection{Sistem Sanitasi}

Sistem pengelolaan limbah manusia (limbah tinja) yang digunakan oleh penduduk Kecamatan Bogor Utara adalah sistem pembuangan setempat (on site). Sedangkan air buangan yang berasal dari kamar mandi, dapur dan tempat cuci ada yang disalurkan ke saluransaluran drainase yang menuju badan sungai. Akan tetapi secara keseluruhan masyarakat sudah memiliki sarana sanitasi pribadi.

\subsubsection{Kondisi Kualitas Air Badan Air Penerima Limbah}

Badan air yakni Sungai Ciparigi menerima limbah cair rumah tangga dari permukiman disekitarnya. Berdasarkan data pengukuran kualitas air pada lokasi sampling memperlihatkan bahwa terjadi pencemaran buangan air limbah rumah tangga (domestik) atau bahan organik yang dicirikan oleh parameter BOD, COD dan E.Coli. Berdasarkan SK Gubernur Jawa Barat Nomer 38 tahun 1991 tentang baku mutu kualitas air maka terlihat bahwa nilai BOD, COD dan $E$ Coli telah melebihi baku mutu air golongan $\mathrm{B}, \mathrm{C}$ dan $\mathrm{D}$.

\subsubsection{Drainase}

Kondisi sistem drainase di sekitar wilayah Kecamatan Bogor Utara secara umum merupakan sistem drainase alam. Sistem drainase yang ada dibedakan sebagai berikut :

a. Sistem drainase di wilayah permukiman Saluran-saluran alam hampir menyebar disetiap kelurahan yang ada. Hal ini berfungsi sebagai saluran pengumpul dari saluran drainase yang ada disekeliling area permukiman. Seperti halnya Kelurahan Bantarjati, Tegalgundil dan Ciparigi dilalui Sungai Ciparigi, Kelurahan Cibuluh, Tanahbaru dan Ciluar dilalui Sungai Ciluar dan Kelurahan Cimahpar dilalui Sungai Cimahpar sedangkan Kelurahan Kedunghalang dilalui Sungai Ciliwung.

b. Sistem drainase di luar wilayah permukiman

Wilayah Kecamatan Bogor Utara dilalui oleh sungai besar yaitu Sungai Ciliwung yang mengalir sampai ke Jakarta. Sungai ini merupakan badan air yang menerima buangan akhir dari anakan-anakan sungai yang mengalir dari Wilayah Bogor Utara dan sebagian Kota Bogor lainnya.

\section{HASIL KAJIAN TEKNIS KELAYAKAN PENERAPAN SISTEM OFF SITE}

Kelayakan suatu sistem sanitasi dapat dievaluasi berdasarkan kondisi fisik daerah dan tingkat kepadatan penduduk. Penentuan analisa kelayakan sistem sanitasi dapat dilakukan dengan skoring dan pembobotan terhadap beberapa parameter yang berpengaruh terhadap pemilihan sistem sanitasi tersebut. Sedangkan skoring tiap-tiap parameter tersebut bertujuan untuk mempermudah dalam penentuan nilai. Untuk lebih jelasnya dapat dilihat pada lampiran Tabel 1.

Kepadatan penduduk ditentukan berdasarkan kriteria sebagai berikut (Anonim, 2003) :

Skala $1(<50$ jiwa/ha) : sangat rendah

Skala $2(50-100 \mathrm{jiwa} / \mathrm{ha}) \quad$ : rendah

Skala $3(100-150 \mathrm{jiwa} / \mathrm{ha}) \quad$ : sedang

Skala $4(150-200 \mathrm{jiwa} / \mathrm{ha}) \quad$ : tinggi 
Skala 5 (>200 jiwa/ha) Permeabilitas : sangat tinggi tanah ditentukan berdasarkan kondisi tanah setempat yang paling dominan dengan penjelasan sebagai berikut (Anonim, 2003) :

Zone 1 : permeabilitas sangat baik, 25-35 $\mathrm{Itr} / \mathrm{m}^{2}, \quad$ tanah cocok untuk pembuangan setempat

Zone 2 : permeabilitas baik, 15-25 $\mathrm{ltr} / \mathrm{m}^{2}$, tanah cocok untuk pembuangan setempat

Zone 3 : permeabilitas cukup, 10-15 $\mathrm{Itr} / \mathrm{m}^{2}$, tanah tidak cocok untuk pembuangan air bekas mandi/cuci

Zone 4 : permeabilitas rendah, $10 \mathrm{ltr} / \mathrm{m}^{2}$, tanah hanya cocok untuk kakus tuang siram

Zona 5 : permeabilitas sangat rendah, $<10$ $\mathrm{Itr} / \mathrm{m}^{2}$, tanah tidak cocok untuk pembuangan setempat

Beberapa parameter yang dipakai sebagai pertimbangan adalah kepadatan penduduk, air tanah dangkal, permebilitas tanah, bentuk muka tanah dan sumber pelayanan air bersih ditujukan untuk menghindari dampak lingkungan yang mungkin timbul. Parameter-parameter tersebut dapat dijelaskan sebagai berikut :

\section{a. Kepadatan penduduk}

Secara kualitatif, daerah pelayanan diarahkan untuk wilayah dengan kepadatan penduduk relatif tinggi. Daerah dengan kepadatan penduduk $>150$ jiwa per hektar sebaiknya diterapkan sistem terpusat atau off site sistem. Mengingat biasanya didaerah dengan kepadatan penduduk tinggi banyak timbul masalah sanitasi. Wilayah Kecamatan Bogor Utara yang mempunyai tingkat kepadatan tinggi adalah Kelurahan Bantarjati dan Tegalgundil dengan tingkat kepadatan penduduk masing-masing 161 jiwa per Ha dan 159 jiwa per Ha. Sedangkan kelurahan Cimahpar mempunyai kepadatan penduduk paling rendah yaitu 30 jiwa per $\mathrm{Ha}$.

\section{b. Air tanah dangkal}

Berdasarkan sifat fisik dan keteknikan tanah dan batuan di wilayah Kecamatan Bogor Utara maka kedalaman muka air tanah berkisar antara 1-2 meter. Hal ini diperkuat dengan kondisi hidrogeologi Kota Bogor yaitu jenis akuifer produktifitas tinggi dengan penyebaran luas melalui celahan dan ruang antar butir.

\section{c. Permeabilitas tanah}

Daerah dengan kelulusan tinggi dan kedalaman muka air rendah dinilai perlu untuk menerapkan off site sistem dalam pengelolaan limbah domestik karena sistem on site dengan tangki septik yang diresapkan akan mengakibatkan pencemaran air tanah. Sedangkan daerah dengan kelulusan rendah dan muka air tanah sangat dalam dinilai tidak mendesak untuk menerapkan sistem off site karena sistem on site dengan tangki septik yang disedot secara rutin tidak akan mencemari air tanah serta biaya relatif lebih murah. Secara umum wilayah Kecamatan Bogor Utara memiliki kondisi permeabilitas tanah sama karena masih berada dalam wilayah geologi sama.

\section{d. Topografi}

Sistem penyaluran air limbah perpipaan diupayakan dilakukan secara gravitasi sehingga kondisi topografi wilayah sangat menentukan dalam penyusunan desain sistem penyaluran air limbah. Kondisi topografi yang berbukit dan bergelombang dengan kemiringan tanah lebih dari $25 \%$ akan menyulitkan dalam sistem penyaluran air limbah. Daerah perbukitan tinggi berlereng curam dan perbukitan bergelombang akan mengalami kesulitan secara teknis jika diterapkan sistem penyaluran air limbah domestik secara gravitasi menuju lokasi IPAL (sistem off site). Keadaan topografi wilayah Kecamatan Bogor Utara bervariasi mempunyai kemiringan lahan sampai $40 \%$ dan berada pada ketinggian 28-300 meter diatas permukaan air laut.

\section{e. Sumber air bersih}

Daerah dengan pelayanan air bersih nonperpipaan tinggi dinilai sangat ditekankan untuk menerapkan sistem off site dan sebaliknya daerah dengan pelayanan air bersih perpipaan tinggi dinilai tidak ditekankan untuk menerapkan sistem off site. Hal ini dikarenakan untuk menghindari pencemaran sumber air bersih yang berasal dari sumur gali (SGL), sumur pompa tangan (SPT) dan pompa listrik oleh air limbah domestik yang dibuang langsung tanpa disalurkan melalui pipa penyalur air limbah menuju sistem pengolahan.

Berdasarkan referensi (Inayati 2004) untuk sistem skoring kelayakan penerapan off site, menyebutkan bahwa skor diatas 3,1 dikatakan layak untuk dapat diterapkan off site. Hasil analisis kelayakan sistem sanitasi dapat dilihat pada lampiran Tabel 2, dengan metode skoring dengan ketentuan-ketentuan seperti pada Tabel 1. Berdasarkan hasil analisa kelayakan sistem sanitasi pada Tabel 2 maka kelurahan yang memperoleh nilai skor total diatas 3,1 yaitu Kelurahan Bantarjati, Kelurahan Tegalgundil, Kelurahan Cibuluh dan Kelurahan Ciparigi dinilai 
layak untuk menerapkan sistem sanitasi terpusat sedangkan kelurahan yang memperoleh nilai skor total dibawah 3,1 yaitu Kelurahan Cimahpar, Kelurahan Tanahbaru, Kelurahan Ciluar dan Kelurahan Kedunghalang dinilai tidak layak untuk menerapkan sistem sanitasi terpusat atau masih layak menerapkan sistem sanitasi setempat. Rencana daerah layanan IPAL Domestik UASB dan DHS, penulis hanya membatasi Perumahan Perum Perumnas Kecamatan Bogor Utara yang meliputi Perumahan Bantarjati I sebanyak 900 rumah, Perumahan Indraprasta I sebanyak 1100 rumah berlokasi di wilayah Kelurahan Bantarjati dan Perumahan Indraprasta II sebanyak 1000 rumah berlokasi di wilayah Kelurahan Tegalgundil. Total pelayanan mencakup 3000 rumah yang terdistribusi masing-masing 2000 rumah di Kelurahan Bantarjati dan 1000 rumah di Kelurahan Tegalgundil.

\section{ANALISIS SURVAI SOSIAL EKONOMI}

Survai sosial ekonomi dilakukan di daerah rencana pelayanan yaitu Perumahan Bantarjati I, Perumahan Bumi Indraprasta I yang berlokasi di Kelurahan Bantarjati dan Perumahan Bumi Indraprasta II yang berlokasi di Kelurahan Tegalgundil. Instrumen survai berupa kuisioner sosial ekonomi masyarakat yang berisi pertanyaan yang bersifat tertutup maupun semi terbuka. Kuisioner yang disebarkan sebanyak 150 eksemplar dengan jumlah sampel responden yang dipilih adalah tiap-tiap rumah tangga penduduk perumahan perumnas secara "proporsional random sampling" yaitu pengambilan sampel secara acak dari populasi penduduk. Untuk menyimpulkan analisis sosial ekonomi lokasi studi, maka digunakan penggolongan (kriteria) dengan ketentuan sebagai berikut (Inayati, 2004) :

C : Tidak sesuai kriteria pemilihan sistem sarana air limbah/tingkat kemauan masyarakat menerapkan sistem off site 0 $-25 \%$

B : Mendekati kriteria pemilihan sistem sarana air limbah/tingkat kemauan masyarakat menerapkan sistem off site $25 \%-50 \%$

A : Sesuai kriteria pemilihan sistem sarana air limbah/tingkat kemauan masyarakat menerapkan sistem off site $>50 \%$

Berdasarkan aspek yang dianalisis pada Tabel 3 menunjukkan bahwa sebagian besar masuk kriteria A, artinya kemauan masyarakat menerapkan sistem off site sangat tinggi yaitu di atas $50 \%$.
Tabel 1. Analisis Sosial dan Ekonomi Lokasi Studi

\begin{tabular}{|c|l|c|}
\hline No & \multicolumn{1}{|c|}{ Aspek yang di analisis } & $\begin{array}{c}\text { Kriteri } \\
\text { a }\end{array}$ \\
\hline 1 & Kemampuan masyarakat & A \\
\hline 2 & Tingkat pengguanaan air bersih & B \\
\hline 3 & Sistem pembuangan limbah tinja & C \\
\hline 4 & $\begin{array}{l}\text { Sistem pembuangan limbah cair (selain } \\
\text { tinja) }\end{array}$ & A \\
\hline 6 & $\begin{array}{l}\text { Keinginan adanya perbaikan sistem } \\
\text { sanitasi }\end{array}$ & A \\
\hline 5 & $\begin{array}{l}\text { Tingkat pengetahuan tentang off site } \\
\text { sistem }\end{array}$ & A \\
\hline 6 & Minat terhadap off site sistem & A \\
\hline 7 & $\begin{array}{l}\text { Alasan ragu terhadap realisasi off site } \\
\text { sistem }\end{array}$ & A \\
\hline 8 & Alasan keberatan realisasi off site sistem & C \\
\hline \multicolumn{2}{|c|}{ Sumber : Hasil Analisa Penulis, 2006 } \\
\hline
\end{tabular}

\section{KESIMPULAN}

Berdasarkan hasil kajian teknis (topografi, elevasi, sistem penyediaan air bersih, permeabilitas tanah) dan survai sosial ekonomi yang dilakukan pada studi kelayakan penerapan Instalasi Pengolahan Air Limbah Domestik UASB dan DHS di Wilayah Kecamatan Bogor Utara, maka dapat diambil beberapa kesimpulan sebagai berikut :

1. Kelurahan Bantarjati dan Tegalgundil dinilai layak untuk menerapkan sistem offsite/terpusat. Hal ini terlihat dari hasil analisis kelayakan sistem sanitasi yang memberikan skor nilai $>3,10$.

2. Hasil survai sosial ekonomi menunjukkan bahwa pengetahuan, kemampuan dan minat masyarakat sangat tinggi untuk menerapkan sistem off site dengan prosentase $>50 \%$.

\section{DAFTAR PUSTAKA}

1. Anonim. 1991. Keputusan Gubernur KDH Tingkat I Jawa Barat No.38 tahun 1991 Tentang Peruntukan air dan Baku Mutu Air pada Sumber Air di Jawa Barat

2. Anonim. 1999. Kebijakan dan Strategi Pengelolaan Air Limbah Domestik. Dirjen Cipta Karya DPU. Semarang.

3. Anonim. 1999. Initial Community Consultation and Preparation of Pilot Sanitation Project, Semarang (Package-1). Dirjen Cipta Karya DPU. Semarang.

4. Anonim. 2000. Final Report Consultancy Services for Initial Community Consultation Works and Preparation for Pilot Sanitation Project in City of Semarang, Arkonin Engineering MP 
5. Anonim. 2001. Peraturan Pemerintah Republik Indonesia No.82 tahun 2001 Tentang Pengelolaan Kualitas Air dan Pengendalian Pencemaran Air

6. Anonim. 2003. Keputusan Menteri Negara Lingkungan Hidup No. 112 Tahun 2003 tentang Baku Mutu Air Limbah Domestik

7. Anonim. 2003. Laporan Final Identifikasi Kegiatan Pengembangan Sarana Air Limbah Metro Semarang.Departemen Permukiman dan Pengembangan Wilayah Direktorat Jendral Pengembangan Perkotaan. Semarang.

8. Anonim. 2003. Pedoman Pengelolaan Air Limbah Domestik Perkotaan.Direktorat Jendral Tata Perkotaan dan Pedesaan. Jakarta

9. Anonim. 2004. Seminar of Waste Water Treatment Technology: The Time for Action.Pusteklim.Yogyakarta

10. Babbit.E and Bauman.1958.Sewerage and Sewage Treatment.John Willy \& Sons, Inc. New York

11. Bachrawi, Sanusi.2000.Pengantar Evaluasi Proyek.Fakultas Ekonomi Universitas Indonesia.Jakarta

12. Gray, Clive dkk. 2002.Pengantar Evaluasi Proyek Edisi Kedua. PT. Gramedia Pustaka Utama. Jakarta

13. Herlambang, Ari, et all, 2002. Publikasi IImiah Teknologi Pengolahan Limbah Cair Industri, Kerjasama Pusat Pengkajian Dan Penerapan Teknologi Lingkungan BPPT Dengan Proyek Pembinaan Dan Pengelolaan Lingkungan Hidup BAPEDALDA Kota Samarinda.
14. Husnan, Suad \& Muhammad, Suwarsono. 2000.Studi Kelayakan Proyek Edisi Keempat. UPP AMP YKPN. Yogyakarta

15. Hindarko.S. 2003. Mengolah Air Limbah Supaya Tidak Mencemari Orang Lain, Jakarta.

16. Inayati, Dini.2004.Perencanaan Penyaluran \& Pengolahan Air Buangan Daerah Pelayanan Blok $P, U, R, Z$ Kelurahan Sendangmulyo.Tugas Akhir

17. Letinga $G$ et.al.2002.Solid Removalin Upflow Anaerobik Reactor. Review Paper Bioresources Technology. Belanda

18. Linsley, Ray. K, et all. 1995. Teknik Sumber Daya Air, Edisi Ketiga, Jilid 2. Penerbit Erlangga, Jakarta.

19. Metcalf and Eddy. 1991.Waste Water Engineering Treatment Disposal and Reuse, Mc Graw-Hill, Inc, Singapura.

20. Moduto.2000. Penyaluran Air Buangan Volume II, ITB, Bandung

21. Nitisemito, Alex S,Drs.Ec \& Burhan, Umar, M, Drs,M.S.2004. Wawasan Studi Kelayakan dan Evaluasi Proyek. PT. Bhumi Aksara.Jakarta

22. Pandebesie.2002.Pengelolaan Sistem Drainase dan Penyaluran Air Limbah, Institut Teknologi Surabaya, Surabaya.

23. Peavy, Howard S. 1985. Environmental Engineering International Edition, McGrawHill Book Co, Singapore.

24. Soeharto, Imam. Ir. 1995.Manajemen Proyek Dari Konseptual Sampai Operasional. Erlangga.Jakarta.

\section{Lampiran 1 :}

Tabel 1. Skoring Parameter Sistem Sarana Sanitasi

\begin{tabular}{|c|c|c|c|c|c|c|c|c|}
\hline \multirow[b]{2}{*}{ No } & \multirow{2}{*}{ Parameter } & \multicolumn{6}{|c|}{ Skor } & \multirow{2}{*}{ Bobo } \\
\hline & & Stn & 1 & 2 & 3 & 4 & 5 & \\
\hline 1 & Kep. Penduduk & Jiwa/ha & $<50$ & $50-100$ & $100-150$ & $150-200$ & $>200$ & $50 \%$ \\
\hline 2 & Air tanah dangkal & $\mathrm{m}$ & $>12$ & $12-8$ & $8-4$ & $4-0$ & $<0$ & $10 \%$ \\
\hline 3 & Permeabilitas tanah & & Zone 1 & Zone 2 & Zone 3 & Zone 4 & Zone 5 & $10 \%$ \\
\hline 4 & Kelerengan & $\%$ & $>40$ & $25-40$ & $15-25$ & $0-2$ & $2-15$ & $10 \%$ \\
\hline 5 & Topografi & & $\begin{array}{l}\text { Bukit } \\
\text { sedang } \\
\text { berombak }\end{array}$ & $\begin{array}{l}\text { Bukit kecil } \\
\text { berombak }\end{array}$ & Berombak & $\begin{array}{l}\text { Bukit } \\
\text { Kecil }\end{array}$ & $\begin{array}{l}\text { Bukit } \\
\text { sedang }\end{array}$ & $10 \%$ \\
\hline 6 & Air bersih perpipaan & $\%$ & $>80$ & $80-60$ & $60-40$ & $40-20$ & $<20$ & $5 \%$ \\
\hline 7 & $\begin{array}{l}\text { Air bersih non } \\
\text { perpipaan }\end{array}$ & $\%$ & $<20$ & $20-25$ & $25-30$ & $30-35$ & $>35$ & $5 \%$ \\
\hline
\end{tabular}

Sumber: Anonim, 2003 


\section{Lampiran 2 :}

Tabel 2. Analisis Kelayakan Sistem Sanitasi

\begin{tabular}{|c|c|c|c|c|c|c|c|c|c|c|c|c|c|c|c|c|c|}
\hline \multirow{2}{*}{ No } & \multirow{2}{*}{ Kelurahan } & \multicolumn{2}{|c|}{$\underset{\text { (jw/ha) }}{\text { Kep.Penduduk }}$} & \multicolumn{2}{|c|}{$\begin{array}{c}\text { Permeabilitas } \\
\text { tanah }\end{array}$} & \multicolumn{2}{|c|}{$\begin{array}{c}\text { Air tanah } \\
\text { dangkal }\end{array}$} & \multicolumn{2}{|c|}{$\begin{array}{l}\text { Air Bersih } \\
\text { perpipaan }\end{array}$} & \multicolumn{2}{|c|}{$\begin{array}{c}\text { Airbersih non } \\
\text { perpipaan }\end{array}$} & \multicolumn{2}{|c|}{ Kelerengan } & \multicolumn{2}{|c|}{ Topografi } & \multirow{2}{*}{$\begin{array}{l}\text { Skor } \\
\text { Total }\end{array}$} & \multirow{2}{*}{ Sistem } \\
\hline & & Harg & Skor & $\begin{array}{l}\text { Jenis } \\
\text { Tanah }\end{array}$ & Skor & $\begin{array}{c}\text { Harga } \\
(\mathrm{m})\end{array}$ & Skor & $\begin{array}{c}\text { layanan } \\
(\%)\end{array}$ & Skor & $\begin{array}{c}\text { Layanan } \\
(\%)\end{array}$ & Skor & Harga & Skor & bentuk & Skor & & \\
\hline 1 & Bantarjati & 161 & 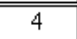 & latosol & 2 & 2 & 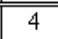 & 79 & 2 & 21 & 2 & $2-15 \%$ & 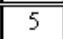 & bukit sedang & $\overline{5}$ & 3.80 & offsite \\
\hline 2 & Tegalgundil & 159 & 4 & latosol & 2 & 1 & 4 & 79 & 2 & 21 & 2 & $2-15 \%$ & 5 & bukit sedang & 5 & 3.80 & offsite \\
\hline 3 & Tanahbaru & 81 & 2 & latosol & 2 & 1 & 4 & 33,61 & 4 & 66,39 & 5 & $2-15 \%$ & 5 & bukit sedang & 5 & 3.05 & on-site \\
\hline 4 & Cimahpar & 29 & 1 & latosol & 2 & 2 & 4 & 33,61 & 4 & 66,39 & 5 & $2-15 \%$ & 5 & berombak & 3 & 2.35 & on-site \\
\hline 5 & Ciluar & 54 & 2 & latosol & 2 & 2 & 4 & 33,61 & 4 & 66,39 & 5 & $2-15 \%$ & 5 & berombak & 3 & 2.85 & on-site \\
\hline 6 & Cibuluh & 106 & 3 & latosol & 2 & 2 & 4 & 22,52 & 4 & 77,48 & 5 & $2-15 \%$ & 5 & bukit kecil & 4 & 3.45 & offsite \\
\hline 7 & Kedunghalang & 93 & 2 & latosol & 2 & 1 & 4 & 22,52 & 4 & 77,48 & 5 & $2-15 \%$ & 5 & berombak & 3 & 2.85 & on-site \\
\hline 8 & Ciparigi & 118 & 3 & latosol & 2 & 1 & 4 & 22,52 & 4 & 77,48 & 5 & $2-15 \%$ & 5 & berombak & 3 & 3.35 & offsite \\
\hline
\end{tabular}

Sumber : Hasil Analisa Penulis, 2006

Keterangan :

* Skor diatas 3.10 layak menggunakan off-site sistem 